Journal of History Culture and Art Research (ISSN: 2147-0626)

Tarih Kültür ve Sanat Araştırmaları Dergisi

Vol. 9, No. 2, June 2020

\title{
DOI: 10.7596/taksad.v9i2.2663
}

Citation: Ataman, K. Y. (2020). Küreselleşen Dünyada Birlikte Yaşamanın Temel Dinamikleri / Basic Dynamics of Living Together in a Globalizing World. Journal of History Culture and Art Research, 9(2), 532-546. doi:http://dx.doi.org/10.7596/taksad.v9i2.2663

\section{Küreselleşen Dünyada Birlikte Yaşamanın Temel Dinamikleri}

\author{
Basic Dynamics of Living Together in a Globalizing World
}

Kemal Yavuz Ataman ${ }^{1}$

\begin{abstract}
In the process of globalization, voluntary or compulsory migrations have become important reasons that make people to live together. Marriages, trade relations, educational movements and tourism have created mobility between countries and communities. Dual citizenship and residence rights, multiple identities and multi-belongings have turned the world into a global society. The rapid development of communication technologies has carried and spread coexistence to all areas of life. The coexistence of people in different geographies has become instantaneous thanks to digital channels. Digital channels enable the sharing of life in every place, with every person, on various topics.

Globalization has made coexistence and living together inevitable. In this context, local elements, structures and cultures are torn between getting the benefits of coexistence in the globalization process and protecting themselves from the disadvantages of globalization. The process is rapidly progressing against local structures and elements. Global values have suppressed the local and traditional values in the process of rapid urbanization. New generations are individualistic, selfinterested, consumption and entertainment oriented. They live independently and free, but their minds and wills are dominated by the global system.
\end{abstract}

Globalization system is the determinant of the consumption-oriented life, including daily life practices, food, clothing and entertainment culture. Future-plans, family, education and all forms of social relations have been under the domination of global culture. Emotions, social opinions and perceptions are shaped by global media tools. Tools themselves do not cause harm or benefit, the content loaded on these tools cause benefit or harm. Programs and contents are not smart, they are developed and implemented by human-beings that are smart. While the global mind is trying to shape the world in all aspects, it educates and manipulates people and destroys local cultural elements and structures.

In this article, the historical process of living together, its social effects, the imperatives it poses and the responsibilities it entails are thoroughly examined and discussed.

Keywords: Globalization, Coexistence, Multiculturalism, Social Integration, Coronavirus.

\footnotetext{
${ }^{1}$ Sakarya Üniversitesi Çalışma Ekonomisi ve Endüstri İlişkileri Doktora Öğrencisi, Sakarya Üniversitesi. E- mail: kyataman@superonline.com
} 
Küreselleşme sürecinde istemli veya zorunlu göçler, insanlığı bir arada yaşamaya zorlayan önemli sebepler haline gelmiştir. Evlilikler, yatırımlar, ticari çalışmalar, eğitim ve akademik amaçlı yerleşimler ve turizm, ülkeler ve toplumlar arasında akışkanlık doğurmuştur. Çifte vatandaşlık ve oturum hakları, çok kimlikli ve çok aidiyetli yaşam, dünyayı küresel topluma çevirmektedir. Iletişim teknolojisinin hızla gelişmesi ise bir arada yaşama alanını ve kapsamını hayatın her alanına taşımıs ve yaymıştır. Farklı coğrafyalarda bulunan insanların bir arada yaşaması dijital mecralar sayesinde anlık hale gelmiştir. Dijital mecralar, her mekânda, her kişiyle, dünyanın her noktasıyla ve birçok konuda yaşamın paylaşılmasını sağlamaktadır.

Küreselleşme bir arada var olmayı ve yaşamayı zorunlu hale getirmiştir. Bu durumda yerel unsurlar, yapılar ve kültürler; küreselleşme sürecinde bir arada yaşamanın faydalarını elde etmekle zararlarından korunmak arasında zorlanmaktadırlar. Süreç yerel yapıların ve unsurların aleyhine hızla ilerlemektedir. Hızlı kentleşme sürecinde küresel değerler, yerel ve geleneksel değerleri baskılamıştır. Yeni nesiller; bireyci, çıkarcı, tüketici, zevk ve eğlence odaklı ve günü birlik yaşamaktadırlar. Bağımsız ve özgür hareket eden, ancak akıl ve iradeleri küresel sistemin hakimiyeti altında olarak yaşamaktadırlar.

Küreselleşme sistemi; günlük yaşam pratikleri, yeme-içme, giyim-kuşam, zevk-eğlence ile tüketim kültürüne odaklı hayatın belirleyicisi olmaktadır. Gelecek planları, aile, eş, çocuk düşüncesi, eğitimi ve tüm toplumsal ilişkilerin formatı küresel kültürün egemenliğine girmiştir. Sevgiler ve nefretler, toplumsal düşünce ve algılar küresel medya araçlarının telkinleri ile şekillenmektedir. Araçlar zarar veya fayda üretmez, onlara yüklenen içerikler, programlar fayda veya zarar vermektedir. Programlar, içerikler akıllı değildir, akıl sahipleri onları belirler, planlar, hazırlar ve uygulamaya koyarlar. Küresel sistemin aklı dünyayı her yönüyle biçimlendirmeye çalışırken, insanları eğitmekte, şartlandırmakta, yerel kültür unsur ve yapıları tahrip etmektedir. Bu durum insanoğlunun birlikte var olma imkânlarını çatışma alanına çevirmekte ve tehdit etmektedir.

Bu makalede birlikte yaşamanın tarihi süreci, sosyal etkileri, ortaya çıkardığı zorunluluklar ve gerektirdiği sorumluluklar kapsamlı bir şekilde incelenmiş ve tartışılmıştır.

Anahtar Kelimeler: Küreselleşme, Bir Arada Yaşama, Çok kültürlülük, Toplumsal bütünleşme, Koronavirüs.

\section{Giriş}

Bir arada yaşamanın tarihi ve doğal süreci incelenecek olursa, insanoğlunun, temel yaşam ihtiyaçlarını gidermek için başkalarına, iş birliğine, dayanışmaya ve anlaşmaya muhtaç olduğu görülür. Bu nedenle her insan topluluğu arasında zamanla yazılı olan- olmayan toplumsal bir sözleşme yapılımıştır. İnsanın yaratııı̧ itibariyle bazı aykırı vasıfları gelişmesinin de unsurlarıdır. İnsan çaresiz kaldığında bu özellikleri sağlıklı bir yöne sevk edebilmektedir. İnsandaki bencillik, saldırganlık ve başkalarına zarar verme gibi yıkıcı eğilimler tabiatından kaynaklanmaktadır. İşte insanı saldırganlıktan alıkoyan ise kendi başına yetersizliğini görmesidir (Çağırıcı, 2015, s. 23). Bu nedenle insan bir arada yaşamaya ayarlı, uyumlu, mecbur ve mahkumdur. Insanların bir arada yaşamaya programlayan Yaratıcı, insanı diğerlerine muhtaç ve yardım alacak halde yaratmıştır.

İnsanlığın yaratılışından bu tarafa aileden çevreye birlikte yaşama alanı ve ağı ihtiyaçlar ve zorunluluklarla başlamıştır. İnsan için üreme, çoğalma, geçinme, yeme içme, giyinme kuşanma, barınma, güvenlik sağlama gibi intiyaçlar bir arada yaşamayı zorunlu kılmıştır. Bir arada yaşanılan aile, akraba, aşiret, arkadaş dost ve çevre teşekkül etmiş, gelişmiştir. Evlilik, akrabalık, ticaret, eğitim, göç, 
fetih gibi kişisel, ailevi ve toplumsal gelişmelerle bir arada yaşama alanı daha da genişlemiştir. Zaman geçtikçe gelişme ve ilerleme amaçı olarak bir arada yaşama alanı genişlemiştir. Ticaretten sonra, devletlerin kurulması ve uluslararası ilişkilerin gelişmesiyle bir arada yaşama alanı sınırları başka ülkelere ve kıtalara uzanmış, insanlar o topraklara yerleşmişlerdir. Bu irtibat, taşınma ve yerleşimler bir arada yaşama kültürünü, ortak değerleri, ilkeleri oluşturmuş, geliştirmiştir. Genellikle ve kural olarak aidiyetler korunmuş, yerel unsur ve kültürlerle bazen uyum, bazen de çatışmalar yaşanmıştır. Temel toplumsal değerler daima muhafaza edilmiştir.

Kıtlıklar, savaşlar, iklim değişiklikleri göçlere sebep olmuş, göçler ise zorluklarıyla beraber insanlığın gelişmesine birikimlerin, bilgilerin taşınmasına, bilinmesine, tanınmasına, keşfine sebep olmuştur. Sınırların olmadığı zamanlarda ticaret, ilim, eğitim, evlilik gibi alanlarda birliktelikler daha kolay yaşanmıştır. Şu bir gerçektir ki, insanların bir arada yaşaması sorunlarla doludur. Zaman zaman çatışmalara, büyük-küçük savaşlara, soykırımlara da sebep olmuştur. Özellikle tarım toplumunda geçim, yaşam ve zenginlik kaynağı sadece tarım olduğu için insanlar toprağı paylaşmak istememişlerdir. Yaşamak için kuvvetli aile, aşiret, kavim merkezli yaşam alanları zaruri olmuş, teşekkül etmiştir. Bütün bunlara rağmen bir arada yaşama alanı ne kadar genişlemişse, insanlığın değişmesi ve gelişmesi de daha çok mesafe almıştır. Çeşitli vesilelerle ortaya çıkan göçler insanların birbirlerini tanımalarına, bilgi, birikim ve kaynaklarının zenginleşmesine sebep olmuştur. Toplumlar her ne kadar bildik, tanıdık ve dar alanda yaşamayı tercih etseler de esasen insanoğlu çoklu yaşamaya fıtrat olarak müsaittir. Türkler, Araplar, Farslar Asya, Avrupa ve Afrika'da, Batılılar Amerika kıtasında yerleşik unsurlar haline gelmişlerdir. Yerleştikleri topraklarda yerel unsurlarla bir arada, sorunlarla birlikte yaşamışlardır. Sınırların çizilmeye başlaması, korunması, vatandaşlıkların tesis edilmesiyle birlikte bir arada yaşamanın coğrafi alanları ve statüsü belirlenmiştir. İmparatorluklar döneminde farklı etnik, dini, mezhebi, kültürel aidiyeti olan insanlar bir arada yaşamışlardır. Ulus devletlerin şekillenmesi ve kurulmasıyla bir arada yaşama belirli etnik, dini, milli değerler, ölçüler ve kültürel yapılar üzerine bina edilmiştir. Ulus devlet sınırları içerisinde kalan azınlıklar, kültürel, dini ve sosyal yapılar bazen görmezden gelinmiş, baskıya ve asimilasyona maruz kalmışlardır.

Her dönemde bir arada yaşamayı en çok etkileyen gelişmeler savaşlar, göçler olduğu için göçmenlerle, göç alan ülkenin yerel unsurları, kültürleri genellikle çatışmışlardır. İradi ve zorunlu göçlerle başka ülkelere yerleşen kişi, aile ve topluluklar kendi dini inanç, düşünce ve kültürleri ile yerel kültür arasında sürekli zorluklar yaşamışlardır. Tarihte ve günümüzde göçmenlerin bir arada yaşama kültürünün gelişmesine, genişlemesine, içselleştirilmesine, zenginleşmesine, hukuki statü kazanmasına çok önemli katkıları ve etkileri olmuştur.

Endülüs İslam Devleti üzerine çalışan İspanyol kültür ve dil tarihçisi Americo Castro (1885-1972) 1948 yılında yazdığı Espana en su Historia adlı eserinde "convivencia" "bir arada yaşama" tabirini ilk olarak kullanan kişidir (Şanal, 2018, s. 61). İspanyol tarihi üzerine çalışma yapan tarihçiler Endülüs Emevi Devleti'nin farklı ve din ve kültürleri başarıyla mecz eden devlet ve toplum yapısını incelemişlerdir. Bu kelime İspanyolca'dır, "bir arada yaşama", "bir arada var olma" anlamına gelmektedir. İngilizce kökenli "Coexistence" kelimesi "bir arada var olma" anlamını taşımaktadır. Bu kelimeler İspanyolca ve İngilizce dillerinde var olan "con" ve "co" kalıplarıyla ifade edilen bu ekler "ile" anlamındadır. Convivencia kelimesi de İngilizce "Coexistence" ve "Living together" kelimelerinin karşılığıdır. "Convivencia” görüşü, İspanyol tarihçiler tarafından Hristiyan, Müslüman ve Yahudilerin Ortaçağ İspanya'sında birlikte barış, huzur, uyum içerisinde yaşamaları olarak ifade edilmiştir". Endülüs'te üç semavi dinin mensubu insanlar nitelikli, karma yaşamı başarmış, birlikte tarih yazmışlardır. "Müslümanlar, Hıristiyanlar ve Yahudiler aynı mekânda, aynı zamanda, aynı dilde ortak yaşama kültürü paylaşmışlar ve geliştirmişlerdir (Şanal, 2018, s.61). 
Avrupa'yı etkileyen, Rönesansın da muharrik unsuru Endülüs Emevi Devleti bir arada yaşamanın, var olmanın çarpıcı, etkili örneğidir. Endülüs alimlerinin Yunan felsefesi üzerine yaptıkları çalışmalar Avrupa'nın yeni bir döneme girmesini sağlamıştır. Müslüman, Hristiyan ve Musevi toplumlar barış içerisinde yaşamanın dışında, ilmi, ekonomik, sosyal ve kültürel açıdan gelişmelerin içinde birlikte yer almışlardır. Bir arada yaşamanın en önemli örneklerinden birisini teşkil eden Endülüs Emevi Devletinde bir arada yaşama hukuki düzenlemelere bağlanmıştır. Etnik, dini unsurların hakları ve sorumlulukları belirlenmiştir. Fırsat eşitliği ve özgürlükler korunmuştur. İslam Hukuku/Fıkhı bu bakımdan önem taşımaktadır (Şentürk, 2016, s. 156). Emeviler birlikte yaşamayı, devlet hayatında, ilimde, eğitimde, ticarette ve sosyal hayatta bütün toplumsal unsurların hayata katılımı ve gelişmesiyle sürdürmüşlerdir. Müslüman ilim adamları yanında Musevi ve Hristiyan ilim adamları da toplumda etkili olmuşlardır. Eğitim kurumları herkese açık hale gelmiştir. Ayrımcılık yapılmamıştır. Endülüs'te ortaya çıkan Rönesans, sadece insanların bir arada yaşamasını değil, madde ile manayı bir arada götürüp insanlığı huzura götürecek içeriğe sahiptir (Aydın, 2014, s. 183). Nitekim Garaudy, Endülüs'te insanlığın tecrübe ettiği bu ruhun insanlık alemini kurtarabilecek yegâne umut olduğunu belirtmiştir. Bir arada yaşamaya örnek olarak Maveraünnehir, Türkistan veya Orta Asya diyeceğimiz coğrafyada önemli bir örnektir. Türklerin Müslüman olmalarından önce Emeviler, sonra Abbasiler bu coğrafyaya ile yerleşmişlerdir. Bölgede Göktürk, Sasani/Fars/İran, Soğd unsurları vardır. Değişik kültürlerin varlığı söz konusudur. Çin ipek, Hint baharat yolunun hayata getirdiği çeşitli zenginlikler vardır. Budist, Zerdüşt, Şaman dininin tesirleri ve mensupları da yerleşik kültürü belirlemişlerdir. Farklı diller konuşulmaktadır. Burada kurulan devletlerle gelişen İslam Medeniyeti çok kültürlü, bir arada yaşamı başarıyla tarih sahnesine koymuşlardır. Yine Hindistan'da yaklaşık 850 yıl süren Müslüman Türkler, harici unsurların, İngilizlerin Hindistan'da nüfuz etmesine kadar çok güçlü bir medeniyeti Müslüman Türkler ve Hindularla birlikte yaşayarak tesis etmiştir. Aynı zamanda Büyük Selçuklu, müteakiben Anadolu Selçuklu Devleti de çok kültürlü, bir arada yaşamın son derece başarılı örneklerini taşımışlardır. Bir arada yaşamanın bir diğer çok önemli örneği ise Osmanlı Devleti'dir. Egemenliği altındaki üç kıtaya yayınlan topraklarda din, ırk, mezhep, topluluklar dikkate alındığında devasa nüfusun bir arada huzurla yaşaması, gelişmesi büyük bir başarıdır. Müslüman, Hristiyan, Musevi ve bu dinlere ait mezheplere mensup topluluklarla Asya, Avrupa ve Afrika'da yaşayan etnik gurupları başarı ile yöneten Osmanlı Devleti için bu sadece siyasi bir başarı değildir. Köklü ahlaki, fikri, irfani, ilmi ve kültürel temellere, değerlere dayanan birikimle bu yönetim gerçekleşmiştir. İslam Devletlerinin başarılarının altında her zaman sağlam hukuki bir yapı, düzen vardır. İslam Hukuku/ fıkhına, Kuran-ı Kerim ve Sünnet'e dayanan birikimle hareket eden devletler, keyfilikten uzak, hak, adalet, insaf ile insanların güvenini kazanmış, güvenliğini sağlamış, yönetmişlerdir. Her kesimi ı toplumun asli unsurları arasına dahil ederek, mutlu ve eşit insan haline getirmişlerdir.

Çağımızın birlikte yaşama için en önemli iki büyük örneği ise göç devleti alan ABD ile iki dünya savaşının yıkımlarından sonra kurulan ve yine birçok göçe ev sahipliği yapan Avrupa coğrafyasıdır. Tarihte özellikle İslam Devletlerinde, günümüzde ise $A B D$ ve $A B$ ülkelerinde ülke dışından gelen unsurların siyasi, sosyal, ekonomik, ilmi, kültürel hayata katılmaları, devlet ve topluma önemli kaynak ve enerji sağladıkları gerçektir. Devlet kademelerinde, üniversitelerde, iş hayatında herhangi bir engele takılmaksınız bu kesimler yer alabildiklerinde, ayrımcılığa uğramadıklarında yerleşik düzen bu insanlardan çok şey kazanmıştır. Gerek tarihte gerekse günümüzde göç yoluyla bir ülkeye yerleşerek büyük başarılara imza atan sayısız insan vardır. Göçler medeniyetlerin kurucu unsurları olmuştur. (Ortaylı, 2017, s. 1) ABD birlikte yaşamayı başarmış bir devlettir. Amerikan değerleri, Amerikan rüyası gibi güçlü ilkeler, sosyal kurumlar, yapılar ve ortaya konan uygulamalar başarıyı göstermektedir. Ancak, 11 Eylül'den bu tarafa gerek İslamofobi, gerekse Müslüman toplumlarda algılandığı şekliyle ABD yöneticilerinin ırkçı yaklaşım ve uygulamaları belirsiz, tehlikeli, endişeli, korku verici bir dönemin 
kapısını açmıştır. ABD'nin çifte standart, emperyalist, çıkarcı, fırsatçı yaklaşımları, söz konusu kazanım ve itibarını sarsmış, güven yitirmesine ve kaygılara sebep olmuştur. Nitekim polis şiddeti ile öldürülen George Floyd ABD içindeki ırkçı, ayrımcı, dışlayıcı, aşağılayıcı sosyal yapının vahametini göstermiştir

$A B$ üyesi ülkelerde de ise durum farklıdır. Avrupa Birliği yüzyıllardır süren mezhep ve etnik kavgaları, Birinci ve İkinci Dünya Savaşının sıcaklığı, yıkımı ve acılarına rağmen ayrılıkların kısmen de olsa geride bırakılmasıyla başarılmıştır. Avrupa ülkeleri intikam ve kinden uzaklaşmışlardır. $A B$, kısa sürede ekonomik, siyasi, sosyal ve kültürel bütünlüğü Avrupa Değerleri adıyla bir müktesebat ortaya koyarak sağlamaya çalışmıştır (Zankova, 2010, s. 21). Demografik sorunları, nüfusun azalması ve iş gücü ihtiyacı nedeniyle istihdam kapılarını Avrupa, kapısını yabancı ülke işçilerine açmıştır. AB sınırları içerisinde üretim ve toplumsal gelişmelerde katkı sağlayan hatta vatandaşlık kazanan bu yabancı unsurlar ile bütünleşmeyi ise Avrupa Birliği yeterince sağlayamamıştır. Bu sınavda başarılı olamamıştır (Onat, 2015 s. 830). Her ne kadar göçle gelen, seçilen ve zorunlu kabul edilen guruplara oturum, çalışma ve vatandaşlık hakları verilse de gelenlerin tam anlamıyla kabullenilmediği, sindirilmediği, hatta dışlanmaya çalışıldığı son yıllarda daha çok görülmeye başlanmıştır (Kaya, 2014, s. 45). Gerek toplumda gerekse siyasi kararlar ve hukuki düzenlemelerde ayrımcılık, ötekileştirme, ırkçılık, İslamofobi $A B$ ülkelerinin birçoğunda ortaya çıkmaktadır. Bir arada yaşama kültürünü geliştiren, kurumlaştıran $A B D$ ve $A B$ hukuki düzenlemeler ve uygulamalarla göçmenlere, bir arada yaşadıkları kişi ve guruplara yasal zeminlerde güvenceler sağlamıştır. "Öteki” unsurların bu ülkelere her alanda iş gücü, üretim, inovasyon, ilim, teknoloji, ticaret alanında önemli katkıları vardır. Bir arada yaşama huzur ve barış içerisinde, ayrımcılık olmadan gerçekleştiğinde toplumsal ivme hızlanmakta ve ülkelerin gelişmesi sağlanmaktadır. Nitekim $A B D$ ve $A B$ her ırk, din, mezhep ve sosyal katmandan unsuru bünyesine dahil ederek bu katma değeri özellikle ekonomide elde etmiştir. Gelinen zamanda değerleri ve ilkeleri ile ters düşmekte, samimiyetleri test edilmekte, sonuçlar ise olumsuz çıkmaktadır. Son yıllarda artan şekilde farklı dini ve etnik guruplara, özellikle Müslüman göçmenlere karşı çifte standartla, nefrete, ötekileştirmeye dönüştüğü için gelecek yıllarda ciddi sorunların yaşanacağı mukadderdir. Aşağıda, birlikte yaşamanın tarihi süreci, sosyal etkileri, ortaya çıkardığı zorunluluklar ve gerektirdiği sorumluluklar 4 başlık altında incelenmiş ve tartışılmıştır.

\section{Genişleyen Yaşama Alanları ve Etkileri}

Küreselleşme sürecinde bir arada yaşama alanı iki şekilde genişlemektedir. Birincisi insanlar çeşitli vesilelerle fiziki, fiili ve doğal olarak, geçici veya uzun süreli bir arada yaşamaktadırlar. İkincisi ise, dijital ve sanal mecrada internet tabanlı iletişim, bilişim, cep teknolojileriyle sosyal medya kanallarıyla ağ toplumunda bir arada yaşama alanı genişlemektedir.

Fiziki ve fiili bir arada yaşama alanı küreselleşme sürecinde daha çok sanayileşme dönemi ve göçlerle hız kazanmıştır. Küreselleşme süreci için çeşitli dönemler başlangıç addedilmiştir. Bu dönemde ekonomik amaçlı göçler olduğu gibi, aynı dönem içerisinde, 20. yüzyılda siyasi, sosyal ve kültürel amaçlı göçler de gerçekleşmiş, bir arada yaşamanın alanı çok yönlü genişlemiştir.

Sanayileşmede döneminde Batı toplumları içerisinde kırsal kesimden şehirlere dahili göçler yanında gelişmekte olan, ülke vatandaşları sanayileşmiş ülkelere akın etmiştir. Türkiye dahil birçok ülkeden Avrupa'ya, Güney Amerika ve Çin'den Amerika'ya göçleri buna örnek olarak verebiliriz. Daha iyi eğitim imkanları, kariyer, yaşam kalitesi amacıyla öğrenci, öğretim üyesi, bilim adamı, teknik insan, yetişmiş, diplomalı vasıfı kişiler de sanayileşmiş, gelişmiş ülkelere göçmen olarak Kuzey-Güney, Doğu-Batı ekseninden ulaşmışlardır (Uğur ve Çalı ve Tatar, 2016:49). Diğer yandan sermaye, bilgi, kariyerleriyle özellikle Batılı ülkeler için maliyeti düşük, önemli göçmenler olarak kabul edilmişlerdir. Halen Batı ülkelerinde çok sayıda Çin, Kore, Pakistan, Hindistan, Türkiye, Balkanlar, Asya, Afrika kökenli insanlar, vasıfı işgücü, ilim, fen ve teknik insanlar, yatırımcılar vardır. 
Gelişmiş ülkeler başta ABD, Kanada, Avustralya, İngiltere, Almanya sistematik ve nitelikli beyin göçü politikalarını yıllardır sürdürmektedirler. Vasıflı kişi ve aileleri teşvik eden, cazip ücretlerle istihdam, kariyer imkanları sunan çalışmalarla her yıl ve sürekli beyin göçü ile göçmenler almaktadırlar.

Bütün bunların yanında ekonomi, istihdam, eğitim, yaşam kalitesi tercihi ve ticari amaçların dışında siyasi ideolojik ve kültürel göçler de yaşanmıştır. Mesela ikinci Dünya savaşından soğuk savaş döneminden sonraki, sanayileşme ile aynı döneme tekabül etmektedir, Nato Paktı, Batı Bloku üyelerinden birbirlerine göçler yaşanmıştır. Varşova Paktı, Sovyet Bloku ülkelerinden, Çin Sosyalist Cumhuriyeti ekseninde aynı ideolojik kamplara tabi ülkeler arasında göçler yaşanmıştır. 1979 Afganistan işgali, İran İslam Devrimi, Körfez Savaşları, Afrika'da Ruanda, Etiyopya'da olduğu gibi iç savaşlar, sınır çatışmaları, etnik ve dini savaşları Filistin, Bosna, Çeçenistan gibi ülkelerden yaşanan savaş ve kargaşalardan büyük göçler olmuştur. Baskı, zulüm, istila, işgal, ihtilal, darbe gibi sebeplerden de çok insan diğer ülkelere göç etmişlerdir. Türkiye'den batıya birkaç çeşit göçler olmuştur. Bunlardan birincisi iş bulmak ve işçi sınıfı olarak yapılan göçlerdir. İkincisi 1960, 1980 ve 28 Şubat 1987 ve en son 15 Temmuz 2016'da yapılan askeri darbe taraftarları veya muarızlarının göçleri, üçüncüsü ise zenginleşmeye bağı olarak vatandaşlık alarak veya sermaye birikimini taşımak sebebiyle yapılan göçlerdir. Bir de evlilik, eğitim, kariyer, ilim, sanat ve teknik amaçlı göçler gerçekleşmiştir.

Son dönemde Arap Baharı, Suriye, Libya, Yemen, Irak gibi çatışma ve savaş bölgelerinden güvenli yaşanabilir, vatandaşlık, oturum hakkı veren, çeşitli imkanlar sunan ülkelere göçler yaşanmaktadır. Türkiye' de son yıllarda ticaret, yatırım, eğitim, güvenlik sebebiyle göç alan, vatandaşlık ve oturum hakkı tanıyan, vasıfı işgücüne imkân sunan ülkelerin başında gelmektedir. Ayrıca, vasıflı, vasıfsız, komşu ve uzak ülkelerden çok sayıda resmi ve kaçak göçmen Türkiye'de bulunmaktadır.

Batı ülkelerine 1960-1970'li yıllarda yerleşen vasıfsı işçilerin çocukları göç ettikleri toplumda, o kültürde yetişmiş, dil öğrenmiş, iyi okullardan mezun olarak hayata atılmışlardır. Yeni yetişen nesiller hayatın her kademesinde, siyasi sosyal, eğitim ve kültürel kurumlarda yer almışlardır.

Küreselleşme sürecinin bir arada yaşama alanını genişleten ikinci yolu dijitalleşmenin etkisiyle gerçekleşmektedir. Bu yolla teşekkül eden ağlar, binlerce yıllık dünya tarihinin, insanlığın birikimlerini, değerlerini sarsmakta, silmekte, yok görmekte, kültürel yapıları yıkmakta ve toplumların genlerini değiştirmeye çalışmaktadır. Dünyanın her noktasında cep telefonu bulunan insanlar aynı programları, oyunları, uygulamaları filmleri izlemekte, haberleri ve yorumları dinlemektedirler. Duydukları, gördükleri ile bazı hususlarda türdeş hale gelmektedirler. Günlük yaşam ihtiyaçlarından yaşam pratiklerine, tarzlarına, tüketim kültüründen aile yapılarına, insan kaynaklarından meslek tercihlerine, kariyer planlamaları dijital mecralar yön vermektedir. (Babacan, 2016, s. 30). Ahlaki anlayış ve davranış kalıpları, değer yargıları, dostluk, arkadaşlık ilişkileri, gelecek planları, vatan, millet, toplum düşüncesi, aidiyet duyguları için müracaat noktası ve belirleyici yer sosyal mecralar olmaktadır. Bu mecralar siyaseti de etkilemektedir (Karakulakoğlu, 2012, S. 39). Küreselleşme sistemi dijital ve sanal olarak bir arada yaşama alanını kodlarını değiştirerek genişletmektedir. Bir arada yaşamanın format ve konsepti değişmiştir. Bütün kültürel ve toplumsal değerler, yapılar, kişiler, kurumlar devreden çıkarılmıştır. Dijiital ağlarla her sınıftan, katmandan insana doğrudan zaman ve mekân olmaksızın, kolay, her an ulaşılmaktadır. Küreselleşmenin bazı aydınlar tarafından "zaman ve mekânın sıkışması" benzetmesi tam olarak vücut bulmaktadır. Dijital ağ toplumu bir arada yaşama alanını genişletirken insanları bir arada yaşadığı kişi, yer, yapı, değer ve kültürlerden uzaklaştırmaktadır. Sanal âlem hem gerçeklik hem hayal alemini birlikte kurgulayan ve yaşatan dünyayı bina etmektedir. On yaşında oyun bağımlığına mahkûm edilmiş Türk çocuğun dünyanın öbür ucundaki oyun arkadaşı altmış beş yaşında ABD'li olabilmektedir. Oyun bir hayaldir, iki oyun arkadaşı ise, gerçektir. Oyunun sonucu hayra alamet 
değildir. Bu hayal ve gerçeğin yeryüzünde milyarlarca karşılığı duygular, düşünceler, inançlar, anlayışlar, kültürlere farklı şekil, konu ve zeminlerde, sosyal mecralarda her an yaşanmaktadır.

Dijital mecra ile bir arada yaşama alanında insanların buluşması, bilgi alış-verişinde olması, işbirliği, paylaşımlar yapılması gibi birçok fayda sağlanmaktadır. Çeşitli kesimlere, alanlara, bilgilere, coğrafyalara ulaşma imkanları vardır. Bu etkileşimle gelişmeye ve ilerlemeye katkı sağlanmaktadır. Birbirlerini sanal alemde tanıyan uzman, akademisyen, araştırmacı, sanatçı, düşünür, ilim adamları, teknisyenler minimum maliyetle, kısa zamanda ve kapsamlı erişimler sayesinde proje geliştirmekte, uygulamaktadırlar. İşbirliği, istişare, inovasyon kolaylıkları sağlanmıştır. Tarihte doğu ve batı medeniyetlerinin merkezi şehirlerde toplanan, konuşan, buluşan, tartışan bir araya gelen çalışan bilginler gelişmenin ve medeniyetlerin önemli simaları olmuşlardır. Küreselleşme sürecinde ise internet, sosyal medya aracılığıyla bilginler iletişim, etkileşim ve paylaşım içindedirler. Bu şekilde devlet, şirket, vakıf, enstitü, ilim ve araştırma kurumlarının bir arada yaşama alanları da çok genişlemiştir. Sosyal medya kanallarına yüklenen toplantılar, projeler, icatlar, kongreler, sempozyumlar, makaleler, kitaplar, kütüphaneler, raporlar geniş, zengin veri bankalarında yer almaktadırlar. Her kurum, kuruluş ve kişi için olumlu anlamda bir arada yaşama alanı genişlemiştir.

Korona sürecinde ulusal ve uluslararası online görüşmeler, seminerler, dersler, toplantılar, programlar icra edilmiştir. İnsanlar fiziken bir aradaymış gibi çalışmaktadırlar, verimlilik artırmıştır. Ulusal ve uluslararası kuruluşlar, eğitim kurumları sanal ortamda işlerini takip etmiş, iletişimlerini sürdürmüşlerdir. Hükümetler, şirketler, yerel ve küresel kuruluşlar aynı şekilde online çalışmalara devam etmektedirler. Hayat sosyal mecralara sığmış, yerleştirilmiştir. Korona pandemi döneminde birçok STK online ders ve seminerlere yönelmişlerdir. Her ne kadar uygulamalı dersler terk edilmek zorunda kalınsa ve derslerin nitelik ve etki gücü zayıflasa da çok kişinin katılımına imkân sağlaması ve vakitten kazanım gibi getirileri insanların daha fazla seminere katılım imkânı doğurmuştur. Doğal olarak insanlar dikey ve derinlemesine olmasa da yatay alanda daha fazla ilgilenmek ve bilgilenmek imkânı elde etmişlerdir.

Bir arada yaşamayı sağlayan her iki fiziki, fiili ve dijital, sanal mecralar yoluyla küreselleşme sürecinde tarihte görülmemiş şekilde insanlar arasında her türlü temas, iletişim, etkileşim şekli ortaya çıkmıştır. Üretim merkezleri, ticari şirketleri, satış, pazarlama ofisleri, eğitim, sivil toplum, kültür kurumları, dünyanın birçok yerinde farkı dini ve etnik kimlikleri bünyesinde taşımaktadır. İnsanın kendi evinde, işyerinde kullandığı ürünlerin altında birçok farklı ülkenin, şirketin imzası, değişik din, inanç, düşünceye sahip, ırka mensup, kadın veya erkek, genç veya yaşlı insanın emeği vardır. Dünyanın en uç noktasında, ülkesinde, köylerinde, dağlarında da dahi bu birliktelik hem gerçek hem de dijitalleşme ile sanal olarak yaşanmaktadır. Küreselleşmenin ekonomik tarafına baktığımızda bir ülke içerisinde değişik etnik ve dini guruplara mensup elemanları çeşitli şekillerde görebilmekteyiz. Bu insanlar yatırım yapmakta, fabrika kurmakta, işyeri açmakta, turizm, inşaat, teknoloji gibi her alanda çalışmayı gerçekleştirebilmektedir. Bu işlerde çalışan dünyanın her yerinden insanla yerel unsurlar birlikte yaşamlarını sürdürmektedirler. Bir ülke birçok ülkeden ithalat yaptığı gibi, birçok ülkeye de ihracat yapmaktadır. Açık bir gerçektir ki, bir arada yaşama genişlemiştir, etkileri çok yönlüdür. Teknolojinin sağladığı imkanlarla gelinen durumu olumlu mecralara çekmek insanlığın zorunlu olduğu bir sorumluluktur, Bu hal insanlığın işbirliği yaparak değerlerini koruması, gelişmesi için de aynı zamanda bir fırsattır.

\section{Birlikte Yaşamanın Ortaya çıkardığı Sorunlar}

Küreselleşme zorunlu bir süreç olarak dünyayı çemberine almıştır. Bir taraftan ülkeler kendi varlıklarını sürdürürken çifte vatandaşlık hakkıyla yerli unsurların haklarına sahip, oturum haklarıyla çeşitli imkanları elde insanlarla kendi toplumu ve insanı arasında nasıl bir denge sağlayacağı konusunda sorunlar yaşanmaktadır. Şirket şubeleri yeryüzüne dağılmıştır, çalışanlarının çalışma ve oturum izinleri 
vardır. Ülkeler farklı kültür, din, inanç sahiplerinin ibadethane ihtiyaçlarına cevap vermektedirler. Turizmin veya iş ilişkilerinin yaygınlaşması farklı kültüre sahip insanların bir araya gelmesini kolaylaştırmaktadır. Ancak, bu insanların büyük çoğunluğu bütün aidiyetlerini muhafaza etmek istemekte, aidiyetleri dayanışma, tanışma açısından çeşitlilik ve zenginlik olarak görmektedirler. Göçmenlerin talepleri ve eriştikleri konumlar yerel kesimlerde rahatsızlığa sebep olmakta, ırkçılık, ayrımcılık, yabancı düşmanlığı, ötekileştirme, Müslümanlar için İslamofobi, siyahlar, zenciler, Afrikalılar için aşağılama, polis baskıları, mahkemeler adil olmayan yargılamalar, çifte standart uygulamaları art arda yaşanmaktadır (Yayla, 2018, s. 25).

Özellikle gelişmiş Batı ülkelerinden bir arada yaşamada yaşanan ikilem şudur: Göçmenler yerleştikleri ülkeye ilimde, ticarette, ekonominin gelişmesinde, teknolojide, sanayide, istihdam alanında katkıda bulunmaktadırlar. Fakat inanç ve düşüncelerine yönelik talepleri yeterince karşılanmamaktadır. Yönetime katılmaları, siyasi mecralara dahil olmaları için yeterli alan açılmamaktadır. Belediye başkanı, milletvekili olanlar ise yerleştikleri ülkelerin değerlerini savunmaya şartlandırılmaktadırlar. İlk vatanlarına, inandıkları din, inanç, ait oldukları kültüre mesafeli olmaya hatta düşman olmaya zorlanmaktadırlar.

Göçmenler ve özellikle Müslümanlar aynı işyerini, mahalleyi kasabayı, şehri paylaştıkları, emek, zaman, ömür harcadıkları, hatta vatandaşı oldukları ülkelerde kendi kültürlerini koruyacak ve yaşatacak taleplerde bulunmaktadırlar. Dijital ağlar onların bu aidiyetlerini canlı tutmalarına imkân vermektedir. Geçici veya uzun süreli bir başka toplumda yalnız veya ailece yaşamak, hayatı ve ortamı paylaşmak bir arada yaşamanın önemli bir aşamasıdır. Sosyal ve kültürel değerler, aidiyetler arasında çatışmalar, çalkantılar yaşanmaktadır. Geçici veya uzun süreli bir başka toplumda yalnız veya ailece yaşamak, hayatı ve ortamı paylaşmak bir arada yaşamanın önemli bir aşamasıdır. Ancak genellikle Batı ülkeleri göçmenleri asimile ederek entegre etmeyi amaç edinmişlerdir. Vatandaşlık almış olsalar da ikinci sınıf muamelesi görmektedirler. Özellikle Müslüman göçmenler çifte standartlara, İslamofobi ile dışlanmaya maruz kalmaktadırlar. Sadece bireysel değil yatırım, ticaret için dünyanın çeşitli ülkelerine ulaşan şirketler gittikleri ülkeye katkı sağlamakta, çalışanlarının dini, sosyal ve kültürel ihtiyaçlarının ise giderilmesini kamu otoritesinden talep etmekte, bazı ülkelerde karşılık bulamamaktadırlar.

İnsanın yeme içme, giyim kuşam, eğlence gibi biyolojik, doğal talepleri yanında dini, fikri, kültürel manevi ihtiyaçları, talepleri, arzuları da vardır. Onlarda anlık, günlük, haftalık aylık olabilir. Bu nedenle yaşadığı yerde bu ihtiyaçlarını gidereceği mekanların olmasını arzu etmektedirler.

Dijital mecralar, ağ toplumuyla asimile ederek, düzleştirerek bir zeminde entegrasyonu ve bir arada yaşamayı sağlamaya çalışmaktadır. Kısa süre, en düşük maliyetlerle büyük başarılar elde etmektedir. Ancak, insanlık çok büyük bedeller ödemektedir. Sosyal mecralar mono/yek bir kültürde insanlığı düz bir zemine çekerek her şeyi düzleştirmektedirler. Eşya, ürün seçimiyle dünyanın her yerinde aynı renk, marka, model kumaş pantolonu, gömleği, ayakkabıyı kullanan insanlar tüketim kültürü ile düzleştirilmiştir (Taylan ve Arkan, 2008, s. 88). AVM'ler aynıdır. Para, kredi, finans araçları düzleştirilmiştir. Düşünceler, algılar, tercihler, idrak, izan, hak ve hukuk anlayışı da düzleştirilmektedir. Küreselleşme bir arada yaşanılan bütün alanları fiziki ve sanal olarak genişletmiştir. Bu genişlik zenginliğin ve çeşitliliğin imhası, tahribi ve insanlığın kültürel anlamda fakirliğe çekilmesidir. İnsanlık esarete ve köleliğe itilmektedir. Bağımlılıkla bu amaç edinilmiştir.

Bir arada yaşamanın başka bir sorunu da şudur: Farklı kültürler yerleşik ve egemen kültürlerin baskısı altındadır. Küresel aidiyetler yerel, milli, dini, ailevi, yöresel aidiyetlerin önüne geçmiştir Mahremiyet, sadakat, değişmiştir, vatan millet, dini inanç, örf, adet gelenek, görenekler tahrip edilmiştir. Küresel köyden küresel dünyaya, küresel topluma ve küresel insana uygun bir tasarım zorunlu hale gelmiştir. Tanışma bilişme açısından zenginlikler olmakla beraber, bütünleşmede birçok zorluklar vardır. Bir 
taraftan gelişme olurken diğer taraftan kriz, çatışma alanlarına girilmektedir. Küresel bazı oluşumlar insanlığın gelişmesi için aşamadır, aynı zamanda toplumlar, devletler, kültürler için risktir. Eğer güçlülerin egemenliğinde bir arada yaşam, farklılıkların yönetimi bir tekel haline gelirse ki, küreselleşme süreci güncel haliyle böyledir, sömürgeci dayatmacı bir sistem dünyayı zorlamaktadır. Devletler interneti yoğun kullanmaktadırlar. Bir düzenleme, hukuk olmadığında çatışmaların internet savaşları üzerinde olacağı muhtemeldir (Ryan, 2019, 236).

Dolayısıyla insandan devletlere, toplumdan sosyal yapılara doğru bir uygulama, çözüm arayışı, beklentisi söz konusudur. Bir arada yaşama zorunludur, sorunludur, bir yol bulmak ise sorumluluktur. Küreselleşme sorunlara rağmen yaşanması zorunlu bir süreçtir. Küreselleşme ile bir arada yaşamı faydalı alana çevirmek ise insanlığın sorumluluğudur. Bir arada yaşama müşterek düşünce, davranış, hareket bağlamında fırsata dönüşebilir., yeryüzünün, insanlığın ekonomik,sosyal ve kültürel olarak gelişmesine çevrilebilir.

\section{Ittifak Alanları}

Küreselleşme süreci devletler ve toplumlararası birlikte iş yapılabileceğini ortaya çıkarmıştır. Hak, adalet, insaf, vicdan ekseninde, katılımcı, çoğulcu bir düzlemde iyi insanların birlikte yaşamı daha iyi şartlara taşıması mümkündür. İnsanlar ve toplumlar iyilik üzerinde işbirliği, istişare, iletişim halinde birlikte yaşamayı zengin hale getirebileceklerdir. Küreselleşme bu şekilde nitelikli birlikte yaşama imkanlarını sağlayacak araçları insanlığa sunmaktadır. Birlikte Yaşamak Manifestosu Fransa'da Haziran 2013'te yayımlanan muhtelif etnik din ve inanca sahip entelektüeller tarafından bir bildiri deklare edilmiştir. Küreselleşme ve birlikte yaşama ile ilgili önemli konular dört başlık halinde dile getirilmiştir. Buna göre, ahlaki, siyasi, ekolojik, ekonomik konularda çok önemli tespitler yapılmıştır. Ahlaki olarak, her bireyin diğerlerinin yaşam hakkına saygılı olması, vicdanıyla hareket, para ve iktidar güçleriyle mücadele etmesi gerekir. Siyasi olarak devlet, hükümet ve siyasal kurumlar ortak insanlık değerlerine göre hareket ederek, ahlaki, çevresel, iktisadi konularda ferdi ve toplumu korumak durumundadırlar. Aşırı zenginlerin hırslarına engel olmak zorundadırlar. Ekolojik olarak ise, insan doğanın sahibi ve efendisi değildir, emanetçidir. ìktisadi olarak ise mutluluk ve refahın para ve malla olmadığı gerçektir. Yeryüzünün varlığı, insanlığın müşterek piyasa ve kamu ekonomisi ile sosyal ve dayanışmacı ekonomi arasında bir dengeyi gerekli kılmaktadır. Bunları gerçekleştirmek için küresel bir topluma aidiyet bilinci, devasa güçlerle mücadele etmek ihtiyaçtır zorunludur. Bu güçler mali, ilmi, entelektüel ve askeri de olabilir (Birikim, s. 1). Esas olan birlikte yaşamanın huzur, barış, adalet ve iyilik üzerinde sağlanmasıdır.

İslam Peygamberi Hz. Muhammed (S.A.V.)'in Veda Hutbesinde ortaya koyduğu ilkeler insanlığın yeryüzünün sonuna kadar riayet edeceği temel gerçekleri ifade etmektedir.

'Rabbiniz birdir, babanız birdir. Hepiniz Âdem'densiniz, Âdem de topraktan yaratılmıştır. Hiç kimsenin başkaları üzerinde soy sop üstünlüğü yoktur. Allah katında üstünlük, ancak takvâ iledir.' İnsanları değerlendirirken ilahî ölçü budur. Hz. Muhammed (S.A.V.) bir Hadis-i Şerifte 'İnsanlar tarağın dişleri gibi eşittir.' demiştir. İslam Halifelerinden dördüncüsü olan Hz. Ali (k.v.) ise 'İnsanlar ya dinde kardeş ya da hilkatte/yaratılışta eştir.' Birlikte yaşama hukukunu temellendirebilecek yegâne ölçü budur. Birlikte yaşamanın ahlakı da bu temel üzerine kurulabilir. (Keleş, 2015, s. 63)

Bilimsel ve teknolojik ilerlemeye rağmen çağın insanı, toplumlar mutsuzdur; savaşlar, sömürüler, yalanlar, çılgınlıklar, zulümler, sefaletler, intiharlar, hastalıklar her yerdedir. İnsanlık özlediği huzur ve düzeni, eşitlik ve kardeşliği insaf ve merhameti, anlayış ve sevgiyi aramaktadır. (Coşan, 1997, s. 3) Öncelikle şunun altını çizmek gerekir: İnsanoğlunun medeni başarısı, çağların birikimi olup; kolektif bir üründür. İş bölümüne, birlikte çalışmaya, düzen ve organizasyona, ihtiyaç vardır. Problemleri çözmek için; ilmin, aklın, mantığın, sevginin, saygının, inancın, şevkin ışığında insanlar el ele çalışmalıdırlar. 
(Coşan, 1997, s. 3) Küreselleşme ve iletişim araçlarının sağladığı imkanlar ile insanlar birbirlerini, ülkeleri, kültürleri tanıma imkanına sahiptirler (Uluç ve Yarcı, 2017, s. 92). Yeni iyi, güzel, doğru, huzurlu, mutlu ve refah içerisinde bir yaşama düzeni kurmaya süreç müsaittir.

Dijital mecralar insanlığın geleceğine büyük katkı sağlayabilir, genişleyen bir arada yaşamı alanı kolektif aklı ve şuuru harekete geçirebilir. Bilginin, birikimin transferi etkileşim insanlığın daha büyük medeniyetlere erişmesini sağlayabilir. İşbirliği, istişare, proje ortaklıkları dünyanın daha yaşanılabilir, müreffeh, barış ve güven içerisinde ilerlemesine neden olabilir. Tarihe baktığımızda alimlerin seyahatleri, göçleri, buluşmaları, yerleşmeleri, eserlerin tercümesine medeniyetlerin teşekkülüne sebep olmuştur. Beytü'l-Hikme, Endülüs, Maveraünnehir, Rönesans dünyanın tanık olduğu kültür, medeniyet ve düşünce merkezleri, şehirler bu şekilde gelişmişlerdir. Dijital mecralarda çok çabuk, sık, güçlü şekilde bir araya gelen, görüşen, konuşan, paylaşan ilim, fikir, teknik sahibi insanlar, uzmanlar, akademisyenler dünyanın gelişmesi, ilerlemesi, sorunları gidermek, güzellikleri temin etmek üzere çok faydalı yeniliklere birlikte emek vererek imza atabilirler. Bu bir zorunluluk ve sorumluluktur. Tarihte olduğu gibi sorumluluğun ilk muhatabı da Müslümanlardır. Müşterek inanç, düşünce alanları üzerinde Müslümanların çabası, çalışması, proje üretmesi, geliştirmesi gerekir.

\section{Bir Arada Yaşama Sorumluluğu ve Yapılması Gerekenler}

Bütün insanlığın katılımı, tüm toplumların dikkate alınması, değerlerin korunması, işbirliği, istişare ve müşterek bir gelişmenin birlikte sağlanması zorunlu hale gelmiştir.

Küreselleşme sürecinde bir arada, farklılıklarla bir arada yaşama, farklıkların yönetimi, yeni kavramların yerleşmesi, hukuk sisteminin, ahlaki düzenin, kurum ve kuruluşların müşterek ve mutabakatla oluşması gerektirmektedir.

Son zamanlarda iyi bir görünüm vermemelerine rağmen Avrupa Birliği ve Amerika Birleşik Devletleri bir arada yaşama ve farklılıkları yönetmeyi farklıları yöneterek bir arada yaşamayı sağlamada mesafe almışlardır. Mücadele dolu tarihçeye, zengin müktesebata sahiptirler. Küreselleşme sürecinde gelişmiş ve gelişmekte olan ülkeler başta olmak üzere bütün ülkelerin bir taraftan milli varlığını sürdürürken, diğer taraftan insan ve kültür akışını, hareketini yönetebilmeyi ve sindirmeyi sağlamaları, başarmaları zorunlu hale gelmiştir. İnsanlar küreselleşme sürecinde iletişim, ulaşım imkanlarına sahip oldukça köklü ve kalııı etkileşime uğramakta, yerleşime yönelmekte, çoklu tercih imkanlarını öncelemekte, çok kültürlü yaşamı seçmektedirler. İ̧, yatırım, eğitim imkanları, zorunlulukları, yeryüzüne yayılan aile, akraba ilişkileri, bağlantılar akrabalıklar doğal bir sürece insanlığı yönlendirmektedir.

Küreselleşme sürecinde devletler ve toplumlar insanın, ürünün, ilmin, bilginin, kültürün, tecrübenin, beynin dolaşımına hem mecbur kalmakta, hem ihtiyaç duymaktadırlar. Dolaşım, hareket ve yerleşim doğal hale gelmiştir. Farklııklarla birlikte, bir arada yaşamak ve yönetmek milli irade, milli egemenlik alanlarını, hukuk sistemlerini, seçimlerden askerlik hizmetlerine kadar birçok hususu, örf, adet, gelenekleri, toplumsal değerleri, değer yargılarını etkilemektedir. Bu süreçte devletler ve toplumlar artıları ve eskileri birlikte yaşamakta, uygulama yöntemleri geliştirmekte, düşünmekte, araştırmakta, zorlanmaktadırlar, hayli süre gecikmektedirler. Oysa bir arada yaşama gelişme ve ilerlemeyi teknoloji iletişim ve ulaşım imkanlarıyla sağlayabilir. Bir arada yaşamanın başarısı ve küresel faydanın sağlanması için iki ana unsurun korunması gerekir: İnsan ve insana ait olan değerlerin, yapıların kurumların korunması, inanç/din, akıl, can, nesil/aile, mal güvenliğinin sağlanması gerekir. Bu beş temel değer yaratılışa uygun düzenin sürmesi için zorunludur (Coşan, 2012, s. 116). İkincisi ise yeryüzünün, çevrenin, kaynakların korunması, adil kullanımı, paylaşılması, sömürüye fırsat verilmemesidir.

Ahlaki düzenin, kültürel yapıların, hakların korunması, tecavüzlerin önlenmesi, çifte standartların kaldırılması, yönetime, kararlara katıımın sağlanması, sosyokültürel düzleştirmenin terk edilmesi 
gerekir. Bir arada yaşama alanının için öncelikle insanın yaşam alanı güvenceye alınmalıdır. Özgürleştirme adına köleleştirmek, esarete almaktan, bağımlıııtan insanlar kurtarılmalıdır.

Küreselleşme sürecinde genişleyen bir arada yaşamanın temel ölçüleri küresel haklar ve ödevler bağlamında tanımlanmalıdır. Çifte kimlik, çifte vatandaşlık, çoklu aidiyet, çoklu kültür, çok kültürlülük, çoklu hukuk düzenlemelerinde tarihi ve güncel örneklerden yararlanılmalıdır.

Küreselleşme süreci insanların bir arada yaşamalarını kolaylaştırmıştır. Bu vesile ile doğal, samimi ve zorunlu ilişkiler ağı kurulmuştur. Bu etkileşimle bir takım endişe ve korkuların giderilmesinin, tanınma, tanışmanın da ne kadar önemli ve yararlı olduğu ortaya çıkmıştır. Küreselleşme araçları, teknoloji, sosyal medya tarihte ilk defa her insanın önüne kendisini ifade etme, bilgiye ulaşma açısından büyük fırsatlar, imkanlar sunmaktadır. Ayrıca yerel kültürlerin bir taraftan tahribi olurken diğer taraftan güncellenmesi ve canlılığını koruması da mümkün hale gelmiştir. Yerelin küresele ulaşması ve dönüşmesi de bu şekilde mümkün olmuştur. İnsanlar tarihte olmadığı ve hayal edilemeyecek düzeyde sayısız kişi ve toplulukla, kültür ve değerle bir arada yaşamaktadırlar. İzlediği kanal, kullandığı sosyal medya araçları, internet yoluyla eriştiği, öğrendiği bilgiler, katılımlar, teknoloji sayesinde elde ettiği kazanımlar, birikimler, erişimler, iletişimlerle çok güçlü bir aktör haline gelmiştir. Sosyal medya gurupları güçlü, güncel sürekli iletişim ve etkileşimle sosyal, canlı organizmalara dönüşmüştür. Siyasi ve sosyal hareketler, dalgalanmalar bu yollarla anlık gerçekleşebilmektedir. illgiler ve tepkiler, kitlesel hareketler anlık olabilmektedir (Sayımer, 2014, s. 98). Ekonomik, sosyal ve siyasi sorunlar ilgililere iletilebilmektedir. Haberleşme anlık ve gerçektir. Mesela bir ürün, bir üretici, bir olay, bir fail, bir beyan, bir cevap anında yayılabilmekte, teyit edilmektedir. Bu durum toplumları canlı ve gelişmeye açık hale getirmiştir. Küresel toplum açık toplum, dinamik bir toplum olmuştur. Dünyada başarılı gelişmelerin bir arada yaşanan toplulukların olduğu ülkelerde gerçekleşmesi dikkat çekicidir. Özellikle çağımızda bu denli bağımlı ve iç içe yaşayan insanlığın erdemli bir küresel toplum haline gelmesi bir arada var olmak bilinci ile gerçekleşebilir. Şüphesiz birtakım değerlerin tanımı, kabulü ve anlamlandırıması önem kazanmaktadır. Küreselleşme ile bir arada yaşama zorunluluk mu, sorumluluk mu, ya da hem zorunluluk hem sorumluluk mu Olduğu gerçekten önemli bir husustur. İnsan doğası itibariyle tek düze yaşama ayarlı değildir Parmak izleri bile farklı olan insanların algıları, zevkleri, renkleri ve keyifleri de farklıdır. İnsan farklıı̆ğ yatkındır, çeşitliliğe, zenginliğe eğilimlidir. Ancak siyasi, ekonomik ve kültürel hegemonyanın dayatması insanları normalden uzaklaştırmaktadır. Küreselleşme araçları yoluyla etkileşim sağlamak, iletişimle, bilgi, birikim, tecrübeyi; sevgi, insaf, merhamet adalet, hikmet sepetinde toplayarak insanlığın bütün değerlerini örgütlemek mevcut teknolojik araçlarla, kolay, düşük maliyetle ve kısa zamanda mümkündür. İnsanların bağımlığını iyiliğe, güzelliğe ve doğruluğa aktararak fıtrata uygun, korku ve endişeye değil, güven ve barışa yönelik, ötekileştiren değil, sevgi ve saygıya dayalı, istikrarlı bir insani düzene kavuşturmak gerekir (Düzgün, 2016, s. 322). Paylaşmaya, diğerkamlığa yönelik, geçmişten ibretle geleceği dikkate alan, çevreye, doğaya ve diğer canlılara da duyarlı bir düzeni elbirliğiyle kurmak zor değildir. İnsanlık bir aradadır, teknoloji sayesinde böyle yaşamaktadır. Bu kapsam ve hız dairesi içerisinde haksızlığa ve hataya dur demek bile, büyük mesafelerin kat edilmesini sağlayacaktır. Bir arada yaşamak bir arada var olmaya dönüşmüştür. Bu alanda Müslümanların tarihi, başarılı geçmişleri, inançları nedeniyle almaları gereken sorumluluk da fazladır.

Zaman insanlık ve yeryüzü için birlikte var olmak, yaşamak, fedakârlık ve duyarlıık zamanıdır. Prangalardan kurtulmak, hegemonyalara meydan okumak zamanıdır (Alatlı, 2014, s. 1377). Bütünleşmek, farklılıkları çatışma unsuru değil, zenginlik olarak ele almak zamanıdır. Farklııkları fark etmek, kültürel zekâ/irfan ile yönetmek, karşı kültürleri tanımak, düşünmek, akletmek, muhakeme etmek zamanıdır. İletişim ve sosyal medya araçlarını, dijital mecraları bu açıdan seçici bir gözle, feraset ve basiretle kullanmak, değerlendirmek, fayda üretmelerini sağlamak gereklidir. 


\section{Sonuç}

Küreselleşme bir gerçektir, bir arada yaşama ise zorunluluk, mecburi bir gerçektir. İnsanlığın geçirdiği bu aşamada, küreselleşme sürecinin olumlu bir gidişata evrilmesi gerekir Bir arada yaşamanın sorumluluk dahilinde devam etmesi zorunluluktur. Aksi halde dünya siyasi, sosyal ekonomik ve kültürel olarak önlenemez kaos, kargaşa, yıkım, savaş ve çatışmalara yönelecektir.

Bir arada yaşama zorunluluktur, sorumluluktur, ayrıca insanlık için fırsattır. Fiziki, fiili ve dijital, sanal bir arada yaşama süreci zorunlu olmakla birlikte insanlığın gelişmesi, birikimlerin, toplanması, paylaşılması yeni, müşterek bir medeniyet için bir imkandır, fırsattır. Tarihte insanlar bir araya gelerek şehirleri, şehirlerde bir araya gelen bilginler, uzmanlar ise medeniyetleri kurmuşlardır. Eskinin şehir kütüphaneleri dijital veri tabanlarıyla erişilmesi kolay küresel kütüphanelerdir. Bu süreçte dijital mecrada zamana ve mekâna bağlı olmaksızın vasıfı insanların buluşması, tanışması, bilişmesi, bilgi, proje ve değer üretmeleri mümkündür.

Korona süreci göstermiştir ki, küresel bir dünya, küresel bir toplumun kaçınılmaz olması kadar, devletlerin bağımsızlık, egemenlik alanlarının korunması, toplumsal değerlerin, sosyal, kültürel yapıların güçlü kalması da zorunlu ve kaçınılmazdır. Küreselleşme sürecinde milliyetçi eğilimler, devletçilik güçlenmekte, yerel kültürler harekete geçmektedir.

Korona süreci ülkelere güvensizlik ve korku pompalamıştır. Yeniden ayakta kalmanın gerek şartı olarak liberal-kapitalist devlet söylemi yerine ulus devlet sistemi öngörülmektedir. Pandemi sonrası küreselleşmenin sona ereceği, ülkelerin üretimlerini kendi içlerinde tutacağı, başka yerlerdeki yatırımları da geri çağıracakları şeklinde görüşlerin ön plana çıktığı görülmektedir. Dünyada birçok alanda değişiklikler beklenmektedir. Bu görüşleri savunan "Antifa” benzeri sosyal organizasyonlar güç kazanmış, (https://www.bbc.co.uk/programmes/w3csvfjf) büyük sermaye sahiplerine, sermaye birikimine karşı çıkmakta, eylemler yapmaktadırlar.

Korona sürecinde görülmüştür $\mathrm{ki}$, küreselleşme yeryüzünde, özellikle gelişmiş ülkelerde tekno bağlantıyı ve bağımlılığı sağlamıştır. Ancak sosyal dayanışma, yardımlaşma ve diğerkamlık kaybolmuştur (https://www.bbc.com/turkce/haberler-dunya-51974391). Korona sürecinde ABD, İngiltere ve Fransa gibi küresel devletler şaşırtıcı şekilde başarısız olmuşlardır. Büyük devletlerden başarılı olanlar ise milli varlıklarını, bağımsızlıklarını yerel üretim araçlarını, sosyal devlet vasıflarını toplumsal dayanışmalarını korumaya çalışan, kültürel değer ve yapılarını belirli oranda sağlam tutan Japonya, Almanya, Türkiye, Çin ve Güney Kore gibi ülkeler olmuştur.

Esas itibariyle sorun küresel sistemin egemen güçlerinin çok uluslu şirketler olması, şirketlerin de faydayı değil, karı/ kazancı öncelemesidir (Kamacı, 2018, s. 83). Oysa, öncelik insana, topluma yönelik uzun süreli faydalı tercihler olmalıdır. Kar/kazanç öne geçtiği zaman insan, ahlak, çevre, değerler önemsiz, küresel sistem önünde engel olarak görülmektedir.

Bir arada yaşama alanını, ulaşım avantajları ve iletişim teknolojisi araçlarını kullanarak, insanı ve çevreyi öne alarak, toplumların, devletlerin ve tüm yeryüzünün menfaatlerini gözeterek geliştirmek mümkündür. Akl-ı selimin hâkim olduğu, irfanî aklın hazırladığı programların, içeriklerin küreselleşme araçlarına yüklendiği bir sistemle bu süreci olumlu hale getirmek mümkündür. Bir arada yaşama zemininin ahlaki bir düzene, hukuki sisteme tabi olması zorunluluk arz etmektedir. Akl-ı selimle, irfanî akılla, ortak akılla, kollektif şuurla, ahlaki düzen ve adil hukuk sistemi ile değerlerin korunması öne alınarak, insanlığın ve çevrenin ortak bir zeminde buluşmasıyla mümkündür.

Gelinen nokta itibariyle küreselleşmenin faydalı, geliştirici taraflarını koruyacak, zararlı, tahripkâr, yozlaştıran, aşındıran yönlerini giderecek şekilde birlikte yaşama düzeninin sağlanması bütün 
insanların, toplumların, devletlerin sorumluluğu ve görevleri olmaktadır. Değerler korunacak, dayanışma geliştirilecek, toplumsal, kültürel yapılar güçlü tutulacak, yeni nesiller geçici zevkler yerine, kalıcı ve uzun vadeli milletlerin, ülkelerin yatırımı olarak yetiştirilecektir. İnsanlığın geleceği için çok uluslu şirketler değil, bütün toplumlar ve devletler birlikte karar verici olacaktır. Bir arada yaşama tekellerin elinde ve araçlarıyla değil, birlikte karar vererek, sorumluluk alarak, hak, adalet, insaf ekseninde hareketle gerçekleşecektir, devam edecektir.

\section{Kaynakça}

Akçetin, N. Ç. (2017). Küreselleşme ve Gücün Gölgesindeki "Demokrasi", Felsefe ve Sosyal Bilimler Dergisi, Sayı: 23, s. 123-138.

Ataman, K. Y. (2018). Göç Hareketlerinin Küreselleşme Üzerinde Olumlu Etkileri,

Uluslararası Avrasya Göç Sempozyumu, Türkistan/Kazakistan Tam Bildiri Kitabı, s.12.

Atçeken, i. H. (2009). İslam Tarihinde Birarada Yaşama Tecrubesi: Asr-ı Saadet ve Endülüs Örneği, İstem, yıl. 7, sayı. 14, s. 41-59.

Ayaydın, Y. \& Ayaydın, H. Y. (2018). "Sosyal Medyanın Değer Oluşturma Sürecindeki Rolünün Öğrenci Görüşleriyle İncelenmesi, Değerler Eğitimi Dergisi, Sayı: 16/35, s. 57-89.

Aydın, C. (2014). Garaudy'nin Gözüyle Endülüs, Derin Tarih, İstanbul.

Babacan, M. E. (2016). Toplumsal Derinlik, Sosyal Medya ve Gençlik, İnsan ve Toplum Dergisi, Sayı: 6/1, s. 23-46.

Bardakoğlu, A. (2015). Birlikte Yaşama İrade ve Ahlakının Dinî Temelleri, DiB Yayınları, Halk Kitapları, sayı: 260, Ankara, s. 13.

Bekiryazıcı, E. (2017). İslam Felsefi Düşüncesinin Endülüs'te Birlikte Yaşama Katkısı

Medeniyet ve Birlikte Yaşam Kültürü, Timav Yayınları, Konya, s. 351.

Birlikte Yaşamak Manifestosu, www.birikimdergisi.com/http://lesconvivialistes.fr

Birekul, M. (2017). Hıristiyan Kökenli Ulusların Avrupası mı, Kozmopolit Bir Avrupa mı? Avrupa'da Çokkültürlülüğün Tarihi ve Sosyolojik Kökenleri Üzerine Bir Tartışma, Medeniyet ve Birlikte Yaşam Kültürü, Timav Yayınları, Konya, s. 308.

Castells, M. (2005). Enformasyon Çağı: Ekonomi, Toplum ve Kültür, Ağ Toplumunun Yükselişi, çev: Kılıç, E. İstanbul, İstanbul Bilgi Üniversitesi Yayınları.

Chomsky, N. (2020). Koronavirüse karşı yapabileceğiniz bir şeyler var, Gazeteyolculuk.net, Erişim 20 Nisan 2020. (https://www.gazeteyolculuk.net/koronaviruse-karsi-yapabileceginiz-bir-seyler-varnaom-chomsky)

Coşan, M. E. (2012). İslam, i̇stanbul, Server Yayınları, s. 116.

Coşan, M. E. (1991). Muttakîlerin En Acil Görevi, ilim ve Sanat, sayı: 28, s. 3.

Coşan, M. E. (1992). Şahsen de Milletçe de En Büyük Düşman: Nefs-i Emmâre, Panzehir, Başmakale, s. 3.

Çağıııcı, M. (2015). İslam'da Birlikte Yaşamanın Ahlakı Temelleri, DiB Yayınları, Halk Kitapları, sayı: 260, Ankara, s. 23. 
Demircan, A. (2016). Teori ile Pratik Arasındaki Uyum ve Çelişkileriyle İslâm Medeniyetinde Birarada Yasama Tecrübesi, Tohum Dergisi, Sayı: 156, s. 15-16.

Dülber, H. (2017). Birlikte Yaşama Ahlakıyla Illgili Hz. Peygamber'in Hayatından Örnek Kural ve Davranış Şekilleri, Timav Yayınları, Konya, s. 349.

Düzgün, Ş. A. (2016). İnsanın Doğası (Fıtratı) ve Özgürlüğü Üzerine, Kelam Araştırmaları Dergisi, Cilt:14, Sayı:2, Ankara, s. 322-342.

Elitaş, T. \& Keskin, S. (2014). Sanal Aidiyet Bağlamında Zihinsel Diaspora: Facebook Örneği, Atatürk Iletişim Dergisi, Sayı: 7, s. 161-187.

Ersöz, S. (2012). Sosyal Medyanın Karanlık Yüzü Sosyal Medyanın Karanlık Yüzü, The Turkish Online Journal of Design Art and Communication, Sayı: 2/4, s. 32-40.

Geray, H. (1997). Emperyalizmin Yeni Masalı Küreselleşme, Ankara: İmge Yayınları.

Gezgin, S. (2005). Küreselleşmenin Medya ve Toplum Üzerindeki Etkileri, İstanbul Üniversitesi illetişim Fakültesi Dergisi, sayı: 21, s. 9-12.

Giddens, A. (2010). Modernite ve Bireysel Kimlik Geç Modern Çağda Benlik ve Toplum, İstanbul, Say Yayınları, s. 37.

Gündoğar, H. (2017). İslam'da Birlikte Yaşamanın Temel Referansları, Medeniyet ve Birlikte Yaşam Kültürü, Timav Yayınları, Konya, s.342.

Güneş, A. (2018). Din Eğitiminin Hedefleri Bağlamında Bir Arada Yaşama Kültürü, Uluslararası Sosyal Araştırmalar Dergis, Cilt:11, Sayı:57, s.837.

Güney, B. (2017). Dijital Bağımlılı̆ın Dijital Kültüre Dönüşmesi: Netlessfobi, Yeni Medya Elektronik Dergi, Sayı:1/2, s. 207-213.

Held, D. \& McGrew, A. (2008). Küresel Dönüşümler: Büyük Küreselleşme Tartışması, Ankara, Phoenix Yayınevi, s. 71-72.

Kamacı, A. \& Turan, M. (2018). "Küreselleşme Sürecinde Çok Uluslu Şirketlerin Ekonomik Açıdan Değerlendirilmesi, Yönetim, Ekonomi, Edebiyat, İslami ve Politik Bilimler Dergisi, Sayı: 3/2, s.81-92.

Karaca, M. (2012). Farklılaşma, Bütünleşme ve Birlikte Yaşama Üzerine, Dicle Üniversitesi Ziya Gökalp Eğitim Fakültesi Dergisi, sayı: 18, s. 226-238.

Kaya, A. (2014). Farklılıkların Birlikteliği, Türkiye ve Avrupa'da Birarada Yaşama Tartışmaları, Hiperlink Yayınları, ìstanbul, s. 45.

Keleş, E. (2015). Hepiniz Âdem'densiniz Âdem ise Topraktan, DiB Yayınları, Halk Kitapları, Sayı: 260, Ankara, s. 63.

Kırık, A. M. (2012). Arap Baharı Bağlamı'nda Sosyal Medya-Birey Etkileşimi ve Toplumsal Dönüşüm, 21. Yüzyılda Eğitim ve Toplum Dergisi, Sayı:1/3, s. 87-98.

Korkmaz, M. \& Osmanoğlu, C. (2019). Küreselleşmenin Birey ve Toplum Hayatına Etkileri ve Din Eğitimi, Manas Sosyal Araştırmalar Dergisi, 8 (Ek Sayı 1), s. 951-967.

Kunduracı, N. (2015). İslam Medeniyetinde Birlikte Yaşama Kültürü, Sosyal Politika Çalışmaları Dergisi, Yıl: 15, Sayı: 34, s. 61-88.

Onat, H. (2015). İslam Kültürüründe Diğer Dinlerle Bir Arada Yaşama Hoşgörüsü, Ankara, s. 830. http://www.ayk.gov.tr/ 
Ortaylı, i. https://www.aa.com.tr/tr/turkiye/1198643

Öngören, H. (2012). Küreselleşme ve Yerel Kültürler, İstanbul Üniversitesi Illetişim Fakültesi Dergisi, s. 449.

Öze, N. (2017). Toplumsal Kültür Haline Gelen Sosyal Medya Kullanımı ve Stratejik Pazarlama İletişimi Aracı Olarak Halkla ilişkilerin Diyalektiği, The Turkish Online Journal of Design Art and Communication, Sayı: 7/2, s. 203-212.

Ryan, J. (2019). İnternetin Geçmişi ve Dijital Gelecek, Tübitak Popüler Bilim Kitapları, Ankara, s. 236.

Sayımer, i. (2014). "Yeni Medya Ortamlarında Ağlar Oluşturan Toplumsal Hareket Deneyimleri, Elektronik Mesleki Gelişim Ve Araştırmalar Dergisi, Sayı:2/2, s. 97-112.

Sinanoğlu, A. (2010). İslâm Medeniyetinde Farklı Kültürlerin Birlikte Yaşamasının İlk Tecrübesi, Ekev Akademi Dergisi, Yıl:14, Sayı: 44, s. 39.

Süleymanov, A. (2018). Solo Yaşam Olgusuna Sosyolojik Bakış, Psikohayat Dergisi, Sayı: 9/19, s. 20-23.

Şanal, E. (2018). Convivencia: Endülüs'te Bir Arada Yaşama Kültürü, İzmir Katip Çelebi Üniversitesi Sosyal Bilimler Enstitüsü Tarih Anabilim Dalı, Yüksek Lisans Tezi, İzmir, s. 61.

Şentürk, R. (2016). Medeniyet ve Değerler: Açık Medeniyet İstanbul Yaklaşımı, Tohum Dergisi, İstanbul, s. 156.

Tarhan, N. (2019). Yeni Medya ve Aile Çalıştayı, Üsküdar Üniversitesi, İstanbul.

(https://uskudar.edu.tr/tr/icerik/3865/yeni-medya-ve-aile-calistayi-uskudar-universitesinde-yapildi)

Taylan, H. H. \& Arklan, Ü. (2008). Medya ve Kültür: Kültürün Medya Aracılığıyla Küreselleşmesi, Selçuk Üniversitesi Sosyal Bilimler Dergisi, Sayı:10/1, s.85-98.

Uğur, A. (2015). Küreselleşme ve İnsan Kaynakları Yönetimi (Ders Notları), Sakarya Yayıncılık, Sakarya, s. 7.

Uğur, A., Çalış, A. S. \& Tatar, T. (2016). Küreselleşme Sürecinde Beyin Göçünün Illgili Ülke Ekonomileri Üzerine Etkileri, Sakarya İşletme Fakültesi Uluslararası İşletme Öğrencileri Kongresi Kongre Kitabı, Cilt:1, Cilt Yayın No:156, 13-14, Sakarya, s. 42-56.

Uğur, A. \& Yasım, Y. K. (2015). Bankacı Kadınların Demografik Özelliklerinin İş-Aile Çatışmasına Etkisi: Ordu İli Örneği: Küreselleşen Dünyada Kadın ve Siyaset, İstanbul Aydın Üniversitesi "Türkiye Araştırmaları Ve Uygulamaları Merkezi", s. 532-561.

Uluç, G. \& Yarcı, A. (2017). Sosyal Medya Kültürü, Sosyal Bilimler Dergisi, Sayı:52, s.88-99.

Varol, S. F. (2017). Medyanın Küreselleşmesi: Neden-Sonuç Ekseninde Bir Değerlendirme, Giftder, Cilt: 5, Sayı:1, s. 400-419.

Yayla, A. (2018). Avrupa Kültüründeki Irkçılığın Tedavisi Yok, Kriter Dergisi, Sayı: 3/30, Erişim 15 Mart 2020. (https://kriterdergi.com/soylesi/prof-dr-atilla-yayla-avrupa-kulturundeki-irkciligin-tedavisi-yok)

Zankova, B. (2010). Diyalog, Anlayış Ve Sosyal Uyum, Avrupa Konseyi Standartları Hakkında Elkitabı, Avrupa Konseyi, s. 21. 